\title{
Dukungan Sosial Keluarga dan Self Efficacy Siswa SMP dalam Menghadapi Ujian Nasional
}

\section{Description of Family Social Support and Self Efficacy of Junior High School Student's in Facing The National Examination}

\section{Yasinta Raharjayanti}

Bidang Penyediaan Air Minum dan Sanitasi, Direktorat Jenderal Cipta Karya, Kementerian Pekerjaan Umum dan Perumahan Rakyat

Email : yasintaraharjayanti@gmail.com

\begin{abstract}
Background: The implementation of the National Examination starting in the 2002/2003 apparently leaves many problems and shortcomings. Changes in the system of the results of Government evaluations can cause anxiety for students who participating in the Computer Based National Examination. Self efficacy with social support is an important component that has to be reviewed to prevent the occurrence of psychological disorders of students in dealing with UNBK. Objective: This research was conducted to see a description of self efficacy with social support so that it can be used as a reference to prevent psychological disorders of students in junior high school ' $X$ ' Method: this research is a descriptive study. The sample of this study was 38 respondents with a sampling technique using total sampling. The instrument used was a questionnaire. Results: The results showed that social support with low category was $44.8 \%$, moderate category was $36.4 \%$ and high category only reached $18.4 \%$. Self efficacy in students is in the high category that is equal to $50 \%$, the moderate category shows the number $28.9 \%$ while in the low category $21.1 \%$. Conclusion: Family social support does not make students feel inferior and reduce their self-efficacy because students can find information from various sources so that their self-efficacy is high.
\end{abstract}

Keyword :Teen, Social Support, Self Efficacy, National Examination

\begin{abstract}
ABSTRAK
Latar Belakang: Penyelenggaraan Ujian Nasional dimulai sejak tahun ajaran 2002/2003 ternyata masih banyak menyisakan permasalahan dan kekurangan. Perubahan sistem dari hasil evaluasi pemerintah dapat menyebabkan kecemasan terhadap siswa peserta Ujian Nasional Berbasis Komputer. Self efficacy dan dukungan sosial merupakan komponen penting yang harus ditinjau untuk mencegah terjadinya gangguan psikologis siswa dalam menghadapi UNBK. Tujuan: Penelitian ini dilakukan untuk melihat gambaran mengenai self efficacy dengan dukungan sosial agar dapat dijadikan acuan untuk mencegah gangguan psikologi siswa pada SMP ' $X$ '. Metode: Penelitian ini merupakan penelitian deskriptif. Sampel penelitian ini sebanyak 38 responden dengan teknik pengambilan sampel menggunakan total sampling. Instrument yang digunakan adalah kuesioner. Hasil: Hasil penelitian menunjukkan bahwa dukungan sosial dengan kategori rendah sebanyak $44,8 \%$, kategori sedang $36,4 \%$ dan kategori tinggi hanya mencapai angka 18,4\%. Self efficacy pada siswa ada pada kategori tinggi yaitu sebesar 50\%, kategori sedang menunjukkan angka 28,9\% sedangkan pada kategori rendah 21,1\%. Kesimpulan: Dukungan sosial keluarga meningkatkan rasa percaya diri. Self efficacy siswa termasuk dalam kategori tinggi, mereka dapat mencari informasi dari berbagai sumber.
\end{abstract}

Kata Kunci: Remaja, Social Support, Self Efficacy, Ujian Nasional 


\section{PENDAHULUAN}

Permendikbud no. 66 tahun 2013 menyebutkan bahwa Ujian Nasional yang disingkat UN merupakan kegiatan untuk mencapai kompetensi siswa di beberapa mata pelajaran tertentu untuk menilai pencapaian Standar Nasional Pendidikan (Menteri Pendidikan dan Kebudayaan, 2013). Tujuan diadakannya Ujian Nasional (UN) ialah untuk meningkatkan mutu pendidikan Indonesia. Ujian Nasional, Ujian Sekolah, dan Ujian Sekolah Berstandar Nasional wajib diikuti oleh peserta didik salah satunya adalah siswa SMA/MA (Kemendikbud, 2017). UN merupakan salah satu upaya pemerintah dalam mengevaluasi pendidikan secara nasional dengan menentukan standarisasi nasional pendidikan (Tilaar, 2006). Hasil UN yang dilaksanakan oleh negara sebagai upaya untuk memetakan masalah pendidikan di Indonesia dan menyusun kebijakan mengenai pendidikan nasional. UN adalah suatu sistem untuk mengevaluasi standar pendidikan dasar dan menengah secara nasional dan persamaan mutu tingkat pendidikan di semua daerah di Indonesia yang dilakukan ileh Pusat Penelitian Pendidikan (Hartanto, 2013).

Kebijakan mengenai UN diatur dalam Undang-undang nomor 20 tahun 2003 tentang Sistem Pendidikan Nasional yang menyatakan bahwa dilakukan evaluasi pendidikan secara nasional sebagai bentuk penyelenggara pendidikan kepada pihak-pihak yang berkepentingan (UU RI No 20 Tahun 2003, 2003). Hasil dari ujian nasional akan digunakan sebagai salah satu pertimbangan untuk memetakan mutu program dan/atau satuan pendidikan, dasar seleksi masuk jenjang pendidikan selanjutnya, serta pembinaan dan pemberian bantuan kepada satuan pendidikan dalam upaya untuk meningkatkan mutu pendidikan.

Penyelenggaraan Ujian Nasional dimulai sejak tahun ajaran 2002/2003. UN telah dilaksanakan sebanyak tujuh belas kali, namun sayangnya dalam rentang waktu yang panjang tersebut, ternyata ujian nasional banyak menimbulkan permasalahan dan kekurangan. Salah satunya adalah masalah kecurangan ujian yang setiap tahun selalu ada. Fenomena kecurangan ini seakan-seakan menjadi rahasia umum. Kecurangan yang terjadi di Sumatera Utara, perwakilan berbagai sekolah di Medan dan Deliserdang membeli kunci jawaban UN seharga 8 juta untuk semua mata pelajaran pada UN 2016. Selain itu di Jombang, peserta UN mendapat pesan berantai mengenai tawaran kunci jawaban dengan harga 1,5 juta (Wurinanda, 2016). Tahun 2015 terjadi kasus terbesar pelaksanaan UN yaitu bocornya naskah soal di internet. Kejadian tersebut membuat Kemendikbud bertindak dan berkoordinasi dengan Menkominfo untuk memblokir tautan google yang berisi naskah soal UN.

Berbagai perbaikan dilakukan secara terus-menerus berdasarkan evaluasi selama sembilan tahun pelaksanaan UN. Salah satu perubahan mendasar yang menyertai penyelenggaraan Ujian Nasional ialah dijadikannya komposisi nilai sekolah sebagai salah satu faktor penentu kelulusan (Indahri, 2014). Ujian Nasional tidak lagi dijadikan syarat satu-satunya untuk lulus dari sekolah. Walaupun demikian, evaluasi belajar ini tetap menjadi hal yang ditakuti oleh siswa maupun lembaga sekolah. Pola kecurangan yang terjadi pun semakin tahun semakin canggih, dengan memanfaatkan kecanggihan teknologi. Bocornya kunci jawab UN dengan mudah didapatkan melalui aplikasi pesan seperti Whatsapp Messenger, Line, Blackberry Messenger (BBM) dan SMS. Canggihnya cara kecurangan itu menjadi penyebab sulit dikendalikannya penyebaran jawaban. Kondisi ini diperkuat oleh penelitian sebelumnya yang menyatakan bahwa peluang kecurangan dan soal bocor menjadi sangat sempit karena soal ujian hanya dapat dibuka beberapa menit sebelum pelaksanaan ujian dilaksanakan, serta siswa hanya dapat mengakses soal ujian pada waktu yang ditentukan dan akun siswa akan otomatis tertutup ketika waktu ujian selesai.

Badan Standar Nasional Pendidikan (BSNP) menyatakan, Ujian Nasional Berbasis Komputer (UNBK) adalah ujian yang menggunakan komputer sebagai media untuk menampilkan soal serta proses untuk menjawab. Perluasan pelaksanaan UNBK dilakukan untuk meningkatkan efisiensi, mutu, reliabilitas, kredibilitas, dan integritas ujian. Perubahan sistem ini dapat menyebabkan kecemasan terhadap siswa peserta UNBK. Salah satu penyebab dari kecemasan adalah keterbatasan fasilitas sekolah. 
Banyak sekolah di Indonesia yang tidak siap mengikuti UNBK. Mayoritas ketidaksiapan sekolah dalam mengikuti UNBK diakibatkan oleh keterbatasan yang dimiliki pihak sekolah. Salah satu sekolah yang memiliki keterbatasan adalah SMP ' $X$ '. Keterbatasan fasilitas di SMP ' $X$ ' antara lain belum adanya komputer atau laptop yang cukup di sekolah dan belum adanya ruangan khusus untuk laboratoium komputer. Kondisi tersebut dibenarkan oleh Kepala Sekolah bahwa SMP ' $X$ ' merupakan salah satu sekolah di Kabupaten Bangkalan yang memiliki keterbatasan fasilitas khususnya komputer sebagai media yang digunakan untuk mengerjakan soal ujian. Kondisi ini dapat menyebabkan kecemasan hingga menimbulkan stress terhadap siswa karena kurangnya latihan pra UN atau try out menggunakan komputer.

Terdapat empat langkah penting dalam memahami suatu masalah, yaitu prinsip SORC yang terdiri dari Stimulus, Organism, Respones, Consequences (Spiegler and Guevremont, 2003). Kasandra Putranto berpendapat dalam berita tempo 23 April 2018, kecemasan dan rasa tertekan tersebut disebabkan karena adanya stimulus (S) menekan, yaitu UNBK (Davies, 2018). Faktor kondisi khas dari karakter anak atau pola pikir (O) menghasilkan respon berupa perilaku (R) cemas dan tertekan, yang kemudian menimbulkan konsekuensi (C). Kecemasan ini dapat menimbulkan turunnya rasa percaya diri siswa dalam mengerjakan soal UNBK. Terdapat hubungan antara kecemasan dan kepercayaan diri, semakin rendah kepercayaan diri semakin tinggi kecemasan dalam menghadapi ujian nasional (Selytania, 2007).

Kecemasan psikologis dalam menghadapi ujian dipicu oleh kondisi pikiran dan perasaan serta perilaku motorik yang tidak terkendali dengan baik. Melihat adanya dampak yaitu kecemasan siswa yang ditimbulkan dari pelaksanaan Ujian Nasional Berbasis Komputer (UNBK) maka hendaknya segera diatasi sejak dini sehingga tidak berdampak buruk terhadap prestasi akademik siswa (Lestari, 2018).

Self efficacy adalah keyakinan terhadap diri sendiri mengenai kapasitasnya agar berada dalam tingkatan yang diharapkan, keyakinan individu dalam memengaruhi kehidupannya, serta bagaimana individu tersebut berpikir, memotivasi diri sendiri dan berperilaku (Bandura, 1994). Siswa dengan self efficacy yang tinggi akan beranggapan bahwa mereka mampu mengerjakan soal ujian atau mampu melakukan aktivitas dengan baik (Santrock, 2007).

Dukungan sosial adalah kesenangan yang dirasakan oleh individu, penghargaan akan kepedulian dan bantuan yang didapat dari seseorang atau kelompok tertentu. Dengan adanya dukungan sosial dapat memberikan penguatan pada individu, menjadikan suasana hati seseorang menjadi lebih positif dan dapat mengubah perilaku individu tersebut dari informasi yang telah didapatkannya, sehingga hal tersebut dapat memengaruhi keyakinan individu (Bandura, 1994).

Ada hubungan antara self efficacy dengan dukungan sosial, karena sebagian remaja banyak menghabiskan waktu dengan keluarga, sekolah, guru dan teman (Schunk and Meece, 2006). Self efficacy dalam penelitian ini merupakan kepercayaan diri siswa dalam menghadapi UNBK. Dukungan sosial keluarga dalam penelitian ini adalah suatu bentuk dukungan terhadap anak yang dapat meningkatkan self efficacy siswa dalam menghadapi UNBK.

Penelitian ini dilakukan untuk mengukur self efficacy dengan dukungan sosial sehingga didapat gambaran mengenai self efficacy dengan dukungan sosial dan dapat dijadikan acuan untuk mencegah gangguan psikologi siswa pada SMP ' $X$ '.

\section{METODE}

Penelitian ini dilakukan di SMP ' $X$ ' yang terletak di Kabupaten Bangkalan. Perbedaan penelitian ini dengan penelitian lain adalah penelitian ini melihat dukungan soail dan self efficacy secara bersamaan. Penelitian sebelumnya hanya melihat dukungan sosial/self efficacy saja.

Penelitian ini adalah penelitian deskriptif yaitu mengumpulkan informasi keadaan yang menurut apa adanya pada saat penelitian. Penelitian ini bertujuan untuk menggambarkan dukungan sosial keluarga dan self efficacy pada siswa SMP dalam menghadapi Ujian Nasional (UN). Sampel penelitian ini adalah siswa SMP ' $X$ ' kelas IX. SMP ' $X$ ' merupakan salah satu 
sekolah yang berada di satu desa di Bangkalan, mayoritas pendidikan dan ekonomi orang tua dan keluarga siswa berada di kelas menengah ke bawah. Selain itu, SMP ' $X$ ' mempunyai keterbatasan fasilitas sehingga penulis tertarik untuk meneliti SMP ini.

Subyek yang diambil ialah siswa SMP kelas IX yang berusia 14-16 tahun dan akan melaksanakan ujian nasional pada saat itu. Pengambilan data dilakukan pada tanggal 16 Desember 2017 di SMP ' $X$ ' dengan memberikan kuesioner kepada 38 siswa kelas IX. Siswa dikumpulkan menjadi satu kelas, peneliti didampingi oleh salah satu pengurus sekolah kemudian menjelaskan teknis dan tata cara pengisian kuesioner. Selanjutnya siswa diberikan waktu sekitar 10 menit untuk mengisi kuesioner tersebut dan peneliti mengambil kuesioner yang telah diisi.

Metode pengambilan sampel ialah total sampling, dimana seluruh siswa turut ikut menjadi responden dalam penelitian ini. Cara ini dipilih karena jumlah siswa hanya 38 orang. Pengumpulan data dilakukan dengan mengumpulkan siswa dalam satu ruangan kelas, kemudian membagikan kuesioner untuk diisi.

Kuesioner yang digunakan terdiri dari 2 macam yaitu kuesioner dukungan sosial keluarga dan self efficacy yang diambil dari penelitian sebelumnya (Maulida, 2017). Pengolahan data dikelompokkan dalam kategori ada dukungan sosial dan tidak ada dukungan sosial, serta memiliki self efficacy dan tidak memiliki self efficacy.

\section{HASIL DAN PEMBAHASAN}

Karakteristik responden siswa kelas 9 SMP ' $X$ ' Kabupaten Bangkalan meliputi jenis kelamin, usia, pendidikan ibu, dan pendidikan ayah. Data karakteristik responden didapatkan dari hasil kuesioner yang dibagikan pada saat penelitian.

Hasil penelitian pada Tabel 1 menunjukkan total responden sebanyak 38 siswa. Distribusi responden berdasarkan jenis kelamin menunjukkan sebagian besar responden berjenis kelamin perempuan yaitu sebanyak 25 orang $(65,8 \%)$, sedangkan sisanya merupakan responden berjenis kelamin laki-laki sebanyak 13 orang $(34,2 \%)$.
Tingkat pendidikan orang tua responden di kategorikan menjadi 4 yaitu tidak sekolah, SD atau tidak tamat SD, SMP atau tidak tamat SMP, SMA atau tidak tamat SMA dan perguruan tinggi. Hasil penelitian menunjukkan hasil yang sama baik pada tingkat pendidikan ibu maupun ayah responden sebagian besar SD/Sederajat yaitu masing-masing sebanyak 18 responden atau sebesar 47,4\% pada pendidikan ibu dan sebanyak 12 responden atau sebesar $31,6 \%$ pada pendidikan ayah.

Tabel 1. Karakteristik Responden Siswa Kelas 9 SMP ' $X$ '

\begin{tabular}{lcc}
\hline \multicolumn{1}{c}{ Karakteristik } & Frekuensi & (\%) \\
\hline Jenis Kelamin & & \\
\hline Laki-Laki & 13 & 34,2 \\
Perempuan & 25 & 65,8 \\
\hline Total & 38 & 100 \\
\hline Umur & & \\
\hline 14 Tahun & 13 & 34,2 \\
15 Tahun & 21 & 55,3 \\
16 Tahun & 4 & 10,5 \\
\hline Total & 38 & 100 \\
\hline Pendidikan Ayah & & \\
\hline Tidak Sekolah & 8 & 21,1 \\
SD/Sederajat & 12 & 31,6 \\
SMP/Sederajat & 10 & 26,3 \\
SMA/Sederajat & 8 & 21,1 \\
PT (D3/D4/S1/S2) & 0 & 0 \\
\hline Total & 38 & 100 \\
\hline
\end{tabular}

Dukungan sosial yang dimaksud dalam penelitian ini adalah dukungan sosial yang didapat melalui sumber natural yaitu orang tua dan keluarga mereka. Pertanyaan maupun pernyataan yang terdapat pada kuisioner sengaja dibuat untuk menanyakan seberapa tinggi dukungan sosial yang responden dapatkan dalam menghadapi Ujian Nasional.

Data dukungan sosial responden didapatkan dari kuesioner dukungan sosial berupa pernyataan kemudian responden diminta untuk memilih alternatif jawaban meliputi sangat setuju, setuju, tidak setuju, dan sangat tidak setuju. Kuesioner Dukungan sosial memiliki 23 pernyataan dukungan sosial yang terdiri dari 4 dimensi yaitu dimensi dukungan emosional (meliputi indikator empati, kepedulian dan perhatian; dan penghargaan dan dorongan untuk maju), dimensi dukungan instrumental (meliputi indikator bantuan berupa materi; dan bantuan berupa tenaga), dimensi dukungan informative (meliputi indikator nasehat, saran, umpan balik dan petunjuk), dimensi dukungan 
pendampingan (meliputi indikator kesediaan meluangkan waktu; dan berbagi perasaan tentang minat atau aktivitas sosial).

Pernyataan kuesioner dukungan sosial terdiri dari pernyataan favourable dan unfavourable. Setiap pilihan jawaban memiliki bobot yang berbeda dengan bobot tertinggi sebesar 4 dan bobot terendah sebesar 1 disesuaikan dengan jenis pernyataan favourable dan unfavourable. Seluruh jawaban responden akan diberi bobot kemudian dijumlahkan untuk menghasilkan nilai skor total dukungan sosial responden.

Tabel 2. Distribusi Dukungan Sosial Siswa untuk Menghadapi Ujian Nasional berdasarkan Dimensi.

\begin{tabular}{llc}
\hline \multicolumn{1}{c}{ Dimensi } & \multicolumn{1}{c}{ Indikator } & (\%) \\
\hline Dukungan Emosional & Empati, kepedulian dan perhatian & 35,3 \\
& Penghargaan dan dorongan untuk maju & 10,7 \\
Dukungan Instumental & Bantuan berupa materi & 7,6 \\
Dukungan Informatif & Bantuan berupa tenaga & 6,8 \\
Dukungan Pendampingan & Nasehat, saran, umpan balik dan petunjuk & 28,6 \\
& Kesediaan meluangkan waktu & 5,2 \\
& Berbagi perasaan tentang minat atau aktivitas & 5,8 \\
\hline & Sosial & $\mathbf{1 0 0}$ \\
\hline
\end{tabular}

Tabel 2 menunjukkan hasil dukungan sosial siswa kelas 9 SMP ' $X$ ' berdasarkan dimensi dukungan sosial. Hasil penelitian menunjukkan dimensi tertinggi yang dimiliki oleh responden yaitu dimensi Dukungan Emosional sebesar $46 \%$.

Distribusi dukungan sosial responden berdasarkan indikator dimensi dukungan sosial, indikator tertinggi yang dimiliki oleh responden adalah empati, kepedulian dan perhatian pada dimensi dukungan emosional. Hasil penelitian menunjukkan siswa kelas 9 di SMP ' $X$ ', hampir lebih dari $69 \%$ keluarganya memahami apa yang siswa rasakan ketika akan menghadapi ujian nasional.

Orang tua yang tidak memerhatikan pendidikan anak dapat berpengaruh terhadap ketidakberhasilan siswa (Pratiwi, 2015). Dukungan emosional berupa empati, kepedulian dan perhatian yang didapatkan oleh responden akan berpengaruh terhadap kesiapan dalam menghadapi Ujian Nasional.

Hasil penelitian dalam indikator penghargaan dan dorongan untuk maju menunjukkan sebagian besar keluarga memberikan pujian ketika anak mendapat nilai yang baik dalam sekolah. Siswa perempuan akan lebih menguasai beberapa pelajaran apabila guru memberi pujian atau penguat yang lebih intensif (Romas, 2006). Siswa perempuan dalam penelitian ini lebih banyak daripada lakilaki yaitu 65 persen. Pujian yang diberikan keluarga juga akan membantu siswa untuk semangat dalam belajar. Kurang lebih separuh orang tua siswa turut membantu memecahkan soal yang tidak bisa dikerjakan. Orang tua siswa juga memberikan pujian ketika anak mendapatkan nilai tryout ujian nasional yang bagus.

Indikator dimensi dukungan sosial terendah terdapat pada indikator kesediaan meluangkan waktu dan berbagi perasaan tentang minat atau aktifitas sosial. Hasil penelitian menunjukkan bahwa hampir separuh orang tua siswa tidak tertarik untuk mendengarkan minat dari siswa itu. Kondisi tersebut bisa disebabkan karena kesibukan orang tua. Menurut data sekolah, mayoritas orang tua responden adalah petani. Tingkat pendidikan orang tua yang rendah dan kesibukan orang tua terhadap pekerjaan mempengaruhi dukungan terhadap responden dalam berbagi perasaan tentang minat atau aktivitas sosial.

Hasil penelitian pada indikator kesediaan meluangkan waktu, pernyataan tertinggi dipilih yaitu ketika siswa sedang jenuh belajar, sebagian orang tua tidak mengajaknya jalan-jalan, padahal refreshing tersebut memengaruhi prestasi belajar. Siswa yang turut ikut belajar menggunakan metode karyawisata membuat siswa aktif dan senang dalam mengikuti pembelajaran (Muchsin, 2013). Kondisi ini selanjutnya berpengaruh terhadap prestasi belajar kognitif siswa 
yang tercapai dengan optimal. Hal tersebut juga berhubungan dengan tingkat pendidikan dan pekerjaan orang tua responden yang menunjukkan mayoritas orang tua siswa SMP ' $X$ ' tidak memiliki kesediaan meluangkan waktu kepada responden karena kesibukan pekerjaan sebagai petani, dan juga karena kurangnya pengetahuan akan pentingnya jalan-jalan terhadap prestasi belajar.

Dukungan sosial pada dimensi dukungan pendampingan yang rendah tersebut tidak menyebabkan rendahnya dukungan informatif seperti nasehat, saran, umpan balik dan petunjuk kepada responden. Hasil penelitian menunjukkan ketika responden meminta saran terhadap suatu masalah, lebih dari 50 persen orang tua siswa memberikan masukan atas pemecahan masalah tersebut. Jika siswa agak tidak enak badan, mayoritas orang tua akan mengantar anak ke sekolah meskipun mereka memiliki kesibukan Ketika siswa dalam kondisi malas belajar, orang tua siswa akan memberikan semangat dan motivasi, selain itu keluarga juga mengingatkan siswa agar tetap semangat belajar.

Tabel 3. Distribusi Dukungan Sosial Responden Siswa Kelas 9 SMP ' $X$ '

\begin{tabular}{lll}
\hline \multicolumn{1}{c}{ Dukungan Sosial } & Frekuensi & \multicolumn{1}{c}{$\%$} \\
\hline Tinggi $(>70)$ & 7 & 18,4 \\
Sedang $(50-70)$ & 14 & 36,8 \\
Rendah $(<50)$ & 17 & 44,8 \\
\hline Total & 38 & 100 \\
\hline
\end{tabular}

Dukungan sosial responden dikategorikan menjadi 3 yaitu dukungan sosial tinggi (apabila mendapatkan skor total >70), dukungan sosial sedang (apabila mendapatkan skor total 50-70) dan dukungan sosial rendah (apabila mendapatkan skor total <50). Hasil penelitian Tabel 3 menunjukkan bahwa sebagian besar siswa kelas 9 SMP ' $X$ ' memiliki dukungan sosial keluarga yang rendah. Dukungan sosial keluarga yang rendah itu dapat disebabkan karena rendahnya pendidikan dan ekonomi dari orang tua siswa.

Dukungan sosial dapat diperoleh dari 2 sumber yakni sumber artificial dan natural. Sumber artificial adalah dukungan sosial yang direncanakan untuk kepentingan orang lainnya, sedangkan sumber natural adalah dukungan sosial yang diberikan melalui orang-orang yang berasal dari lingkungan sekitarnya, orangtua, keluarga, teman dll dan didapat secara spontan tanpa direncanakan (Tumanggor, Ridho and Nurochim, 2017).

Tinggi rendahnya dukungan sosial yang didapat oleh seseorang dapat dipengaruhi oleh beberapa faktor salah satunya adalah pendidikan. Tingginya dukungan sosial keluarga dapat dipengaruhi oleh latar belakang pendidikan orangtua dan ekonomi (Widanarti and Indati, 2002). Hal ini dikarenakan oleh orangtua dengan latar pendidikan yang tinggi memiliki kesadaran yang tinggi pula akan kebutuhan dukungannya sebagai orangtua kepada anaknya untuk memaksimalkan pendidikannya. Selain itu, ekonomi juga dapat dijadikan sebagai faktor penentu tinggi rendahnya dukungan sosial yang didapat. Hal ini dikarenakan ekonomi memiliki peran utama dalam pemberian dukungan sosial keluarga dalam bentuk penyediaan sarana dan prasarana yang dibutuhkan anak untuk memaksimalkan proses belajarnya.

Sebagian besar siswa SMP ' $X$ ' kelas IX memiliki dukungan sosial yang rendah, hal ini dikarenakan oleh latar belakang pendidikan orangtua yang rendah. Informasi ini didapat melalui data sekolah yang menyatakan lebih dari 63\% orangtua siswa SMP ' $X$ ' memiliki latar belakang pendidikan rendah, rata-rata latar belakang pendidikan orangtua murid siswa kelas IX adalah SD. Berdasarkan pengakuan dari kepala sekolah, faktanya latar belakang pendidikan dapat mempengaruhi dukungan sosial. Hal ini dibenarkan oleh kepala sekolah melalui data kehadiran rapat wali murid yang masih rendah. Sedangkan kehadiran wali murid dalam rapat sekolah dapat dijadikan sebagai wujud dukungan sosial terhadap belajar anak. Kehadiran wali murid dalam suatu pertemuan yang diadakan sekolah termasuk suatu bentuk partisipasi nonfisik yang berupa dukungan moril (Rahayu, 2015).

Faktor lain yang dapat mempengaruhi dukungan sosial selain pendidikan yaitu ekonomi (Widanarti and Indati, 2002). Semakin rendah latar belakang ekonomi siswa, semakin rendah pula dukungan sosial yang diberikan. Begitu pula ekonomi rendah dapat disebabkan oleh pendidikan yang rendah. Jika latar belakang pendidikan orangtua/wali murid mayoritas rendah maka besar kemungkinan mayoritas latar 
belakang ekonomi siswa juga rendah. Status ekonomi rendah juga sejalan dengan latar belakang pendidikan yang rendah. Sebaliknya, jika masyarakat berpendidikan tinggi akan memiliki peluang lebih besar untuk memiliki status perekonomian yang tinggi (Basrowi and Juariyah, 2010). Jika diselaraskan dengan fakta di lapangan, berdasarkan keterangan kepala sekolah SMP ' $X$ ' menyatakan bahwa memang mayoritas siswa memiliki perekonomian yang rendah, mayoritas orangtua mereka hanya bekerja sebagai buruh tani dan pekerja serabutan tanpa gaji tetap. Maka dapat disimpulkan bahwa sebagian kecil responden yang memiliki dukungan sosial tinggi adalah mereka yang memiliki latar belakang pendidikan yang lebih baik daripada siswa lainnya.

Data Self efficacy responden didapatkan dari kuesioner Self efficacy berupa pernyataan kemudian responden diminta untuk memilih alternatif jawaban meliputi sangat setuju, setuju, tidak setuju, dan sangat tidak setuju. Kuesioner Dukungan sosial terdiri dari 24 pernyataan Self efficacy. Pernyataan kuesioner Self efficacy terdiri dari pernyataan favourable dan unfavourable. Setiap pilihan jawaban memiliki bobot yang berbeda dengan bobot tertinggi sebesar 4 dan bobot terendah sebesar 1 disesuaikan dengan jenis pernyataan favourable dan unfavourable. Seluruh jawaban responden akan diberi bobot kemudian dijumlahkan untuk menghasilkan nilai skor total Self efficacy responden.

Tabel 4. Distribusi Self Efficacy Responden Siswa Siswa Kelas 9 SMP ' $X$ '

\begin{tabular}{lcc}
\hline \multicolumn{1}{c}{ Self Efficacy } & Frekuensi & $\%$ \\
\hline Tinggi $(>70)$ & 19 & 50 \\
Sedang $(50-70)$ & 11 & 28,9 \\
Rendah $(<50)$ & 8 & 21,1 \\
\hline Total & 38 & 100 \\
\hline
\end{tabular}

Masa remaja merupakan suatu periode transisi yang didalamnya terjadi perubahan fungsi fisik, kematangan kognitif, kematangan sosial dan kematangan emosional yang terjadi sangat cepat (Mulia, Elita and Woferst, 2014). Siswa SMP kelas 9 sudah bisa dikatakan telah mengalami kematangankematangan tersebut, sehingga tingkat kepercayaan dirinya bisa menjadi lebih kuat.
Self efficacy responden dikategorikan menjadi 3 yaitu Self efficacy tinggi (apabila mendapatkan skor total $>70$ ), Self efficacy sedang (apabila mendapatkan skor total 50-70) dan Self efficacy rendah (apabila mendapatkan skor total <50). Tabel 4 menunjukkan bahwa sebagian besar siswa memiliki self efficacy yang tinggi. Self efficacy pada penelitian ini merupakan kepercayaan diri seorang siswa dalam menghadapi ujian nasional. Siswa yang duduk di kelas IX SMP ' $X$ ' merupakan anak usia remaja. Remaja seringkali diidentikkan dengan karakteristik yang khas. Remaja memiliki kepercayaan diri yang tinggi dan kurang peduli dengan lingkungan sekitarnya. Remaja yang memiliki kepercayaan diri yang tinggi akan percaya terhadap kompetensi dirinya . la memiliki pendapat sendiri tentang pandangan hidup, sehingga meskipun dukungan sosial keluarga kurang terhadap siswa yang tergolong rendah mereka tetap memiliki kepercayaan diri yang tinggi dalam menghadapi UN. la merasa mampu berdiri dengan kakinya sendiri tanpa bantuan siapapun.

Perkembangan fisik dan psikososial pada remaja terjadi dengan cukup pesat. Salah satu aspek perkembangan psikososial yang penting ialah perkembangan resiliensi yaitu kemampuan untuk beradaptasi dan tetap teguh dalam situasi sulit (Reivich and Shatte, 2008). Sesuai dengan referensi diatas maka dapat dikatakan bahwa dalam menghadapi ujian nasional remaja mampu berdaptasi dan mempunyai keteguhan hati yang tinggi untuk menghadapi situasi yang dianggap sulit dan menakutkan tersebut.

Kepercayaan diri yang dimiliki oleh siswa-siswa di SMP ' $X$ ' bersumber dari berbagai macam faktor yang telah dijabarkan diatas. Faktor yang tidak kalah penting ialah faktor lingkungan sekitar siswa tersebut. Apabila lingkungan tersebut baik dan banyak yang percaya akan kemampuan dirinya, maka hal itu akan menularkan ke teman-teman lainnya. Lingkungan keluarga juga berpengaruh pada kepercayaan diri remaja. Walaupun hasil dari dukungan sosial keluarga diatas termasuk rendah, tidak menutup kemungkinan siswa dapat terpapar dari dukungan sosial temanteman sebayanya. Ada hubungan antara dukungan teman sebaya terhadap 
kepercayaan diri seseorang (Hapasari and Primastuti, 2014).

Dukungan sosial keluarga yang kurang bisa menjadi faktor penyebab kepercayaan diri, apalagi jika siswa tersebut tidak berusaha bersosialisasi dengan lingkungan lain selain keluarga, ia akan sulit terpengaruh oleh lingkungan sosial yang lain seperti teman sebaya disekitarnya. Informasi yang didapat dari kepala sekolah menyebutkan bahwa ada beberapa siswa yang tidak peduli dengan guru-guru, bahkan ketika guru sudah berusaha mendekat kepada siswa tersebut. Padahal menurut penelitian sejenis, guru yang menanamkan kepada siswa untuk selalu berani membuat siswa merasa lebih percaya diri (Fiana, 2017).

Hasil penelitian menunjukkan bahwa kepercayaan diri siswa cukup tinggi untuk menghadapi ujian nasional. Tidak ada siswa yang merasa dirinya tidak dapat mengatasi ujian nasional ini. Hanya 15 persen siswa yang yang tidak mempunyai kemauan untuk berusaha mengerjakan soal ujian nasional ini. Mayoritas siswa juga meyakini bahwa setiap soal memiki tingkat kesulitan yang bermacam-macam dan yakin akan bisa mengerjakannya dengan baik. Masih banyak siswa yang khawatir untuk menghadapi ujian nasional yaitu sebesar $76 \%$. Secara psikologis, kecemasan menghadapi ujian dipicu oleh kondisi pikiran, perasaan dan perilaku motoric yang tak terkendali (Lestari, 2018).

Hasil penelitian penyebutkan bahwa $14 \%$ siswa merasa ia tidak akan berhasil menghadapi ujian nasional walaupun telah berusaha sekuat tenaga. 14\% siswa tersebut merupakan 9 orang yang masuk dalam kategori sedang pada Tabel 4. Kondisi ini tentu memprihatinkan dan menjadi tugas bersama untuk menumbuhkan kembali semangat dan keyakinan pada siswa, bahkan ada 7\% siswa yang merasa dirinya tidak akan lulus ujian padahal ikut ujian pun belum ia lakukan.

Lebih dari separuh siswa menyukai mengerjakan soal yang telah dicontohkan oleh gurunya dan akan bertanya langsung jika tidak mengerti dan mereka merasa jawaban dari guru sudah memecahkan masalah dalam mengerjakan soal tersebut. $30,8 \%$ dari siswa menyatakan setuju bahwa semakin banyak tugas membuat siswa merasa pusing, 30,8\% lainnya mengatakan tidak setuju akan hal itu, hal ini menunjukkan hasil yang imbang antara siswa yang bisa melakukan multitasking dan siswa yang tidak bisa melakukan multitasking.

Self efficacy memainkan peran kunci dalam meregulasi motivasi diri. Mereka membentuk keyakinan tentang apa yang bisa mereka lakukan, menetapkan tujuan untuk diri mereka sendiri dan merencanakan tindakan untuk mewujudkannya. Tingkatan motivasi dapat tercermin dalam pilihan suatu tindakan dalam mewujudkan tujuan, intensitas dan ketekunan usaha yang dilakukannya

Terdapat faktor-faktor yang memengaruhi Self Efficacy seseorang (Bandura, 1994). Pertama ialah faktor orientasi kendali diri. Apabila individu mencapai suatu orientasi pengendalian internal akan mengarahkan dan mengembangkan cara-cara yang sukses dalam mencapai tujuan. Self efficacy menunjukkan perasaan dalam diri individu bahwa ia yakin dapat mengatasi suatu permasalahan dalam hal ini ketika saat ujian. Orientasi kendali diri bersifat internal juga diperlukan untuk mengembangkan self efficacy yang positif. Hasil dari penelitian ini menggambarkan bahwa semua siswa akan berusaha menyelesaikan masalahnya sendiri dan percaya akan kemampuan dirinya sendiri.

Faktor lainnya ialah faktor situasional. Self efficacy bergantung pada faktor kontekstual dan situasional. Situasi-situasi tertentu membutuhkan keterampilan yang lebih dan terdapat risiko yang lebih tinggi pada situasi lain, sehingga self efficacy dapat bervariasi. Hasil penelitian menunjukkan bahwa semakin banyak aktivitas yang dikerjakan maka semakin siswa akan semakin percaya akan kemampuan pada dirinya. Semakin banyak aktivitas maka semakin banyak risiko yang mungkin terjadi dan hal itu juga membutuhkan keterampilan yang tinggi.

Faktor terakhir ialah faktor intensif eksternal. Faktor intensif eksternal atau reward yang diterima individu dari orang lain dapat mempengaruhi self efficacy. Semakin besar intensif atau reward yang diperoleh individu dalam penyelesaian tugas, maka akan semakin tinggi derajat self efficacy nya. Salah satu yang dapat meningkatkan self efficacy adalah competence contingent self efficacy yakni intensif atau reward yang diberikan oleh 
orang lain yang merefleksikan keberhasilan seseorang dalam melaksanakan atau menguasai tugas tertentu. Hampir semua siswa akan menanyakan hal yang tidak dimengerti kepada gurunya, sehingga guru juga bisa dikatakan sebagai intensif eksternal pada siswa yang akan melaksanakan ujian nasional.

Dukungan sosial yang rendah tidak selalu akan menyebabkan self efficacy yang rendah pula, meski seharusnya self efficacy dan dukungan sosial memang saling mendukung. Banyak sekolah yang telah melakukan persiapan menghadapi Ujian Nasional, salah satu caranya adalah dengan menyiapkan mental siswa. Pernyataan dari kepala sekolah mengungkapkan bahwa sekolah benar telah melakukan persiapan menghadapi Ujian Nasional seperti mengadakan program Binsus (Bimbingan Khusus) diluar jam belajar mengajar dan mengadakan tryout sehingga dapat meningkatkan kepercayaan diri siswa.

Kepercayaan diri dapat diciptakan melalui berbagai hal, bukan hanya melalui dukungan keluarga. Adanya sosial media saat ini juga dapat menjadi salah satu faktor pemicu, karena melalui sosial media, remaja dapat mengeksplorasi dirinya. Bagi para remaja, media sosial dianggap sebagai tempat yang tepat untuk melakukan eksplorasi pencarian identitas (Felita et al., 2016).

\section{SIMPULAN}

Dukungan sosial siswa kelas 9 SMP ' $X$ ' berdasarkan dimensi dukungan sosial menunjukkan dimensi tertinggi yang dimiliki oleh responden yaitu dimensi Dukungan Emosional diikuti oleh dimensi Dukungan Informatif Dimensi dukungan sosial terendah yang dimiliki oleh dimensi Dukungan Pendampingan. Indikator tertinggi yang dimiliki oleh responden adalah empati, kepedulian dan perhatian pada dimensi dukungan emosional, sedangkan indikator dimensi dukungan sosial terendah terdapat pada indikator kesediaan meluangankan waktu dan berbagi perasaan tentang minat atau aktifitas sosial.

Tingkat pendidikan dan pekerjaan orang tua berpengaruh terhadap dukungan sosial yang diberikan kepada anak. Pendidikan orang tua responden yang rendah serta tidak adanya kesediaan meluangkan waktu karena kesibukan pekerjaan menyebabkan responden memiliki dukungan sosial yang rendah.

Mayoritas responden siswa kelas 9

SMP ' $X$ ' memiliki self efficacy yang tinggi. Kepercayaan diri responden yang tinggi diperoleh dari banyaknya persiapan yang telah dilakukan oleh pihak sekolah dalam menghadapi Ujian Nasional, serta tingginya minat responden dalam mencari informasi soal-soal latihan untuk ujian nasional.

\section{DAFTAR PUSTAKA}

Bandura, A. (1994) Self-efficacy. Encycloped. Edited by I. V. S. Ramachaudran. New York: Academic Press.

Basrowi and Juariyah, S. (2010) 'Analisis Kondisi Sosial Ekonomi dan Tingkat Pendidikan Masyarakat desa Srigading, Kecamaan Labuhan Maringgai, Kabupaten Lampung Timur', Jurnal Ekonomi \& Pendidikan, 7(1), pp. 58-81.

Davies, A. P. (2018) UNBK Buat Anak Anda Cemas dan Stres? Simak Kata Ahli. Jakarta. Available at: https: / /gaya.tempo.co/read/108 2320/unbk-buat-anak-andacemas-dan-stres-simak-kata-ahli.

Felita, P. et al. (2016) 'Pemakaian Media Sosial Dan Self Concept Pada Remaja', Jurnal Ilmiah Psikologi MANASA, 5(1), pp. 30-41.

Fiana, W. (2017) Peran Guru dalam Menumbuhkan rasa Percaya Diri pada Siswa Tunanetra (Studi Kasus Pola Pendidikan di SLBA'Aisyiyah Ponorogo). Universitas Muhammadiyah Ponorogo. Available at: http: / / eprints.umpo.ac.id/3618/.

Hapasari, A. and Primastuti, E. (2014) 'Kepercayaan Diri Mahasiswi Papua Ditinjau Dari Dukungan Teman Sebaya', Psikodimensia, 13(1), pp. 60-72. doi: 10.24167/PSIKO.V13I1.278.

Hartanto, S. (2013) 'Ujian Nasional (UN), Masih Perlukah?', Widyaiswara LPPKS. Available at: http://lppks.kemdikbud.go.id/id/ kabar/ujian-nasional-un-masihperlukah.

Indahri, Y. (2014) Ujian Nasional Tahun 2014. Jakarta.

Kemendikbud (2017) Peraturan Menteri 
Pendidikan dan Kebudayaan Republik Indonesia Nomor 3 Tahun 2017 Tentang Penilaian Hasil Belajar oleh Pemerintah dan Penilaian Hasil Belajar oleh Satuan Pendidikan. Jakarta: Kementerian Pendidikan dan Kebudayaan RI. Available at: http://simpuh.kemenag.go.id/reg ulasi/permendikbud_03_17.pdf.

Lestari, M. R. D. (2018) 'UNBK di Tingkat SD Dinilai Tambah Stres Anak, Ini Saran Peneliti', NetralNews, 8 January. Available at: https://www. netralnews.com/ne ws/pendidikan/read/122449/unbk .di.tingkat.sd.dinilai.tambah.stres

Maulida, A. N. (2017) Hubungan Antara Dukungan Sosial Keluarga dengan Self Efficacy Menghadapi Ujian Nasional. Universitas Airlangga. Available at: http://repository.unair.ac.id/661 $13 /$.

Menteri Pendidikan dan Kebudayaan (2013) Peraturan Menteri Pendidikan dan kebudayaan Republik Indonesia Nomor 66 Tahun 2013 tentang Standar Penilaian Pendidikan. Jakarta.

Muchsin (2013) Pengaruh Penggunaan Metode Karyawisata terhadap Prestasi Belajar Kognitif IPS Kelas IV Sekolah Dasar. Universitas Negeri Yogyakarta. Available at: http:/ / eprints.uny.ac.id/15645/1 /skripsi muchsin pgsd \%2709.pdf.

Mulia, L. O., Elita, V. and Woferst, R. (2014) 'Hubungan Dukungan Sosial Teman Sebaya Terhadap Tingkat Resiliensi Remaja Di Panti Asuhan', Jom Psik, 1(2), pp. 1-9.

Pratiwi, N. K. (2015) 'Pengaruh Tingkat Pendidikan, Perhatian Orang Tua, dan Minat Belajar Siswa Terhadap Prestasi Belajar Bahasa Indonesia Siswa SMK Kesehatan di Kota Tangerang', Jurnal Pujangga, Vol. 1(2), pp. 75-105.

Rahayu, L. P. (2015) Partisipasi Orang Tua Siswa Dalam Menumbuhkan Motivasi Belajar Siswa Kelas VI SDN Panggang Kecamatan Sedayu Kabupaten Bantul Tahun Pelajaran 2014/2015. Universitas Negeri Yogyakarta. Available at: https://eprints.uny.ac.id/16566/.

Reivich, K. and Shatte, A. (2008) The
Resience Factor: 7 Essential Skill for overcoming life's Inevitable Obstacle. New York: Broadway Books.

Romas, M. Z. (2006) 'Pengaruh Pujian Terhadap Prestasi Belajar Matematika pada Siswa Kelas 4 Sekolah Dasar', Jurnal Psikologi, 2, pp. 1-9.

Santrock, J. . (2007) Psikologi Pendidikan. Jakarta: Kencana.

Schunk, D. H. and Meece, J. L. (2006) Self-Efficacy Development in Adolescence. Edited by \& T. U. In F. Pajares. Greenwich: Information Age Publishing.

Selytania, L. (2007) 'Hubungan Antara Kepercayaan Diri dengan Kecemasan Menghadapi Ujian Nasional pada Siswa Kelas III SMU'. Available at: https://docplayer.info/29901008Hubungan-antara-kepercayaandiri-dengan-kecemasanmenghadapi-ujian-nasional-padasiswa-kelas-iii-smu-lilis-selytaniasukarti-intisari.html.

Spiegler and Guevremont (2003) Contemporary Behavior Therapy. edisi ke e. USA: Thomson Wadsworth.

Tilaar, H. A. R. (2006) Standarisasi Pendidikan Nasional: Suatu Tinjauan Kritis. Jakarta: Rineka Cipta.

Tumanggor, R., Ridho, K. and Nurochim (2017) Ilmu Sosial dan Budaya Dasar. edisi keti. Jakarta: Kencana.

UU RI No 20 Tahun 2003 (2003) 'UndangUndang Republik Indonesia Nomor 20 Tahun 2003 Tentang Sistem Pendidikan Nasional'. Available at:

http://luk.staff.ugm.ac.id/atur/U U20-2003Sisdiknas.pdf.

Widanarti, N. and Indati, A. (2002) 'Hubungan antara dukungan sosial keluarga dengan self-efficacy pada remaja di SMU Negeri 9 Yogyakarta', Jurnal Psikologi, (2), pp. 112-123.

Wurinanda, I. (2016) 'Beragam Kecurangan UN Terulang Setiap Tahun', Okezone, 10 April. Available at: https://news.okezone.com/read/ 2016/04/09/65/1358480/beragam -kecurangan-un-terulang-setiap- 
tahun. 